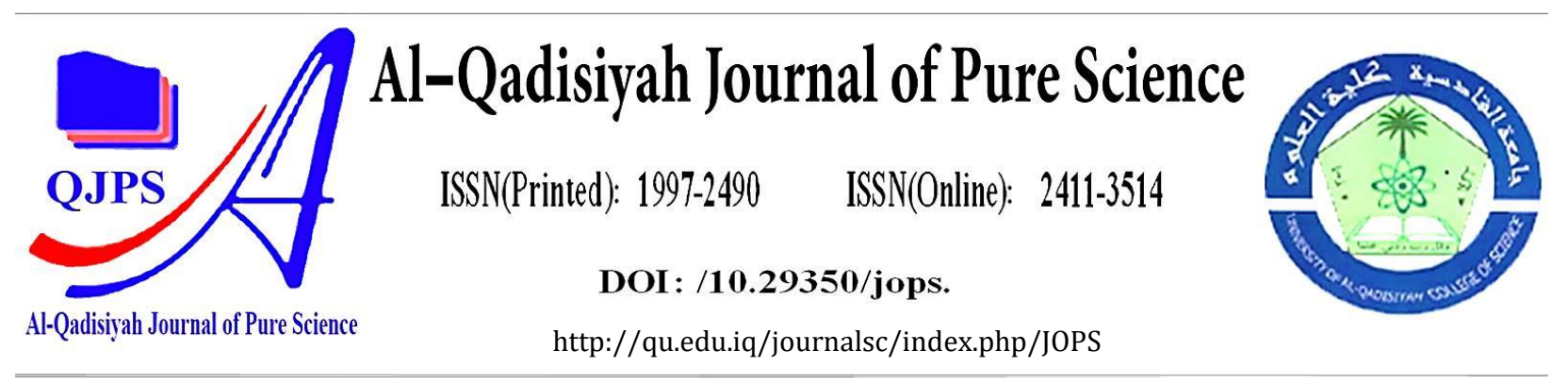

\title{
Synthesis, Characterization of Thiazolidin-4-one, Oxazolidin-4-one and Imidazolidin-4-one Derivatives from 6-Amino-1,3- dimethyluracil and evaluation of their Antioxidant and Antimicrobial Agent
}

\begin{tabular}{|c|c|}
\hline Authors Names & ABSTRACT \\
\hline $\begin{array}{l}\text { b. Suaad M. H. Al-Majidi } \\
\text { Article History } \\
\text { Received on: 11/06/2021 } \\
\text { Revised on: } 2 / 7 / 2021 \\
\text { Accepted on: 7/7/2021 } \\
\text { Keywords: } \\
\text { Uracil, Thiazolidin-4-one, } \\
\text { Oxazolidin-4-one, } \\
\text { Imidazolidin-4-one, } \\
\text { Antioxidant and } \\
\text { Antimicrobial activity. } \\
\text { DOI: } \\
\text { https://doi.org/10.29350/jops. } \\
\text { 2021.26. 4.1346 }\end{array}$ & $\begin{array}{l}\text { In this study, a new series of 6-amino-1,3-dimethyluracil derivative with } \\
\text { 6-(3-substituted } N \text {-benzylidene)-1,3-dimethyl pyrimidine-2,4-dione-6-yl } \\
\text { derivatives which were synthesized by using one pot synthesis. The reaction } \\
\text { of } 6 \text {-amino-1,3-dimethyluracil and different aromatic aldehyde in ethanol } \\
\text { yielded Schiff bases. In the subsequent step reaction of Schiff bases with } 2 \text { - } \\
\text { mercaptoacetic acid, 2-chloroacetic acid and 2-amino acetic acidn in } \\
\text { Tetrahydrofuran yielded five membered heterocyclic rings of 6-amino-1,3- } \\
\text { dimethyluracil derivative which includes: 2,3-thiazolidin-4-one, 2,3- } \\
\text { oxazolidin-5-one, 2,3-imidazolidin-4-one derivatives. The structures of } \\
\text { newly synthesized compounds were confirmed by their physicochemical } \\
\text { and spectral means FTIR, } 1 \text { HNMR and }{ }^{13} \mathrm{CNMR} \text {. The synthesized compounds } \\
\text { were evaluated in vitro for antioxidant and antimicrobial activities against } \\
\text { four types of bacteria and four types of fungi. }\end{array}$ \\
\hline
\end{tabular}

\section{Introduction}

Uracil and its derivatives are one of the most an important class of compounds because these molecules can act as both nucleophiles and electrophiles (Singh, 2019). Uracil's estimated that deamination of cytosine leads to up to 500 uracil residues in a single human cell each day, Besides uracil displays as antihyperthermophilic (Shi et al., 2019). Uracil derivatives have a extensively spectrum of pharmacological such as Anticancer and Antibacterial (Sanduja et al., 2020), Antioxidant (Nayab et al., 2020), Anti-leukemia (Długosz-Pokorska et al., 2020), Cytotoxicity and AntiHIV-1/2 (Novakov et al., 2020) and Antidiabetic (Spasov et al., 2019). In particular, thiazolidinone derivatives have drawn attention and have a wide range of biological properties, in addition to existing in the structure of many natural products (Genc Bilgicli et al., 2020). Thiazolidinones as cholinesterase 
inhibitors and promising compounds against memory decline in Alzheimer's disease, which is associated with cholinergic dysfunctions in rat brain (da Silva et al., 2020). Also thiazolidinone derivatives used as inhibits oesophageal cancer cell proliferation (Wang et al., 2020), anticervical cancer activity (Abbas and El-Karim, 2019), antitubercular agent (Deshmukh et al., 2019), Antibacterial (Cheddie et al., 2019), Anti-Toxoplasma (Abdizadeh et al., 2020), Anti-Cytotoxicity and Anti-inflammatory (Shawky et al., 2020) in addition of Anti-hepatitis-C (Hassan et al., 2019). Besides these, oxazolidinones are the latest class of inhibitory effects exerted on the mitochondrial function of megakaryoblastic cells appear to be particularly protracted (Milosevic et al., 2019) and treatment of skin and skin Structure infections (Santos et al., 2020). At the sametime, Imidazolidinones can improve the epidermal barrier function of facial skin, which is exposed to the sun on a daily basis(Iriyama et al., 2019). Anti-inflammatory and Analgesic activity (El-Sharief et al., 2019), Antiviral (Swain and Mohanty, 2019) and potent antileishmanial agents (Ramu et al., 2019).

\section{EXPERIMENTAL:}

\section{Materials and Instruments}

Chemicals used in this research are supplied from BDH, Fluka, Merck and Sigma Aldrich companies and used without further purification. In addition to melting points were uncorrected and registered by digital Stuart scientific SMP3 melting point device. While, Thin layer chromatography (TLC) used to check purity and homogeneity of synthesis compounds. FTIR spectra of the synthesized compounds in the (4000-600) $\mathrm{cm}^{-1}$ spectral range were recorded on SHIMAZU FTIR-8400 Fourier transform Infrared spectrophotometer using $\mathrm{KBr}$ discs. ${ }^{1} \mathrm{H}-\mathrm{NMR}$ and ${ }^{13} \mathrm{C}-\mathrm{NMR}$ spectra were recorded on BRUKER 500MHz in Iran, instrument using TMS as internal reference and DMSO- $\mathrm{d}_{6}$ as a solvent. Spectrophotometer were recorded by Apel PD-303-spectrophotometer, japan.

Synthesis of 6-(3-substituted $N$-benzylidene)-1,3-dimethyl pyramid-ine-2,4-dione-6-yl (1-6) (AlAdhami and Al-Majidi, 2016)

A solution of (2.0 g, $0.0129 \mathrm{~mol})$ 6-amino-1,3-dimethyluracil, (0.0129 mol) aromatic aldehydes in $(15 \mathrm{~mL})$ absolute ethanol solvent were mixed thoroughly with a catalytic (3-5) drops of glacial acetic acid, then the mixture refluxed in water bath up to (5-6) h., and the product was then dried, after evaporating the excess solvent and recrystallized from chloroform. Some of the physical properties and yield of compounds (1-6) are listed in Table (3.37).

\section{Synthesis of 1,3-dimethyl-6-[2-(3-substituted phenyl) thiazolidin-4-one-3-yl]-pyrimidine-2,4- dione-6-yl (7-12) (Genc Bilgicli et al., 2020)}

In this step, $(0.0041 \mathrm{~mol})$ of Schiff bases (1-6) and 2-mercaptoacetic acid $(0.3 \mathrm{~mL}, 0.0041 \mathrm{~mol})$ in THF (10 mL) was added gradually. The reaction mixture was then heated to reflux up on (18-20) h. After refluxing the reaction mixture was followed neutralized by addition of sodium bicarbonate solution $5 \%$ to remove unreacted 2-mercaptoacetic acid. The product was filtered and washed with water then further purification was done using recrystallized from ethanol. Some of the physical properties and yield of compounds (7-12) are listed in Table (3.45).

Synthesis of 1,3-dimethyl-6-[2-(3-substituted phenyl) oxazolidin-5-one-3-yl]-pyrimidine-2,4dione-6-yl (13-18) (Al-Majidi and Hama, 2015) 
Using a round bottom flask $(50 \mathrm{~mL})$, a mixture of $(0.0021 \mathrm{~mol})$ Schiff bases (1-6) in THF (10 $\mathrm{mL})$ was added to a well-stirred solution of chloroacetic acid $(0.2 \mathrm{~g}, 0.0021 \mathrm{~mol})$ and mixed thoroughly with catalytic few drops of triethylamine in THF solvent. The solution was refluxed for (12-15) h., after cooling the solution, the crude precipitate was filtered and recrystallization using ethanol. Some of the physical properties and yield of compounds (13-18) are listed in Table (3.49).

\section{Synthesis of 1,3-dimethyl-6-[2-(3-substituted phenyl) imidazolidine-4-one-3-yl]-pyrimidine-2,4-} dione-6-yl (19-24) (Al-Majidi and Hama, 2015)

To a mixture of Schiff bases (1-6) $(0.0021 \mathrm{~mol})$ was stirred in $(9 \mathrm{~mL})$ of THF solvent, 2aminoacetic acid $(0.25 \mathrm{~g}, 0.0021 \mathrm{~mol})$ in $(5 \mathrm{~mL})$ of THF was refluxed for $(\mathbf{1 6 - 2 0}) \mathrm{h}$. Then, the resulted mixture was filtered after cooling to room temperature, washed and recrystallized from acetone. Physical properties and yields of compounds (19-24) are listed in Table (3.53).

Table1- Physical properties and FTIR spectral data $\mathrm{cm}^{-1}$ of the synthesized compounds (1-6)

\begin{tabular}{|c|c|c|c|c|c|c|c|c|c|c|}
\hline \multirow[b]{2}{*}{ No. } & \multicolumn{4}{|c|}{ Physical properties } & \multicolumn{6}{|c|}{ Major FTIR Absorption $\mathrm{cm}^{-1}$} \\
\hline & Structure & M.P. ${ }^{\circ} \mathrm{C}$ & $\begin{array}{c}\text { Yield } \\
\%\end{array}$ & Color & $\begin{array}{l}v(\mathrm{C}-\mathrm{H}) \\
\text { Arom }\end{array}$ & $\begin{array}{l}v(\mathrm{C}-\mathrm{H}) \\
\text { Aliph }\end{array}$ & $\begin{array}{r}v(C=0) \\
\text { Amide }\end{array}$ & $\begin{array}{c}v(C=N) \\
v(C=C) \\
\text { olefinic }\end{array}$ & $\begin{array}{c}v(C=C) \\
\text { Arom }\end{array}$ & $\begin{array}{l}\text { Other } \\
\text { bands }\end{array}$ \\
\hline 1 & & $134-136$ & 74 & White & 3006 & 2954 & $\begin{array}{l}1733 \\
1673\end{array}$ & 1654 & $\begin{array}{l}1598 \\
1585\end{array}$ & - \\
\hline 2 & & $179-181$ & 76 & $\begin{array}{c}\text { Off } \\
\text { White }\end{array}$ & 3095 & 2956 & $\begin{array}{c}1677 \\
\text { Overlap }\end{array}$ & 1654 & 1610 & - \\
\hline 3 & & $140-142$ & 85 & White & 3066 & 2956 & $\begin{array}{l}1733 \\
1668\end{array}$ & 1652 & $\begin{array}{l}1610 \\
1596\end{array}$ & $\begin{array}{c}v(\mathrm{C}-\mathrm{Cl}) \\
1163\end{array}$ \\
\hline 4 & & $138-140$ & 88 & White & 3091 & 2927 & $\begin{array}{c}1672 \\
\text { Overlap }\end{array}$ & 1649 & $\begin{array}{l}1604 \\
1581\end{array}$ & $\begin{array}{c}v(\mathrm{O}-\mathrm{H}) \\
3332\end{array}$ \\
\hline 5 & & $158-160$ & 71 & White & 3095 & 2952 & $\begin{array}{l}1733 \\
1679\end{array}$ & 1656 & $\begin{array}{l}1616 \\
1583\end{array}$ & $\begin{array}{r}v(\mathrm{O}-\mathrm{H}) \\
3357\end{array}$ \\
\hline 6 & & $192-193$ & 90 & $\begin{array}{l}\text { Pale } \\
\text { Yellow }\end{array}$ & 3056 & 2956 & $\begin{array}{c}1679 \\
\text { Overlap }\end{array}$ & 1645 & $\begin{array}{l}1614 \\
1562\end{array}$ & $\begin{array}{c}\left(\mathrm{NO}_{2}\right) \\
\text { asym. } \\
1514 \\
\text { sym. } \\
1344\end{array}$ \\
\hline
\end{tabular}

Table 2- Physical properties and FTIR spectral data $\mathrm{cm}^{-1}$ of the synthesized compounds (7-12)

\begin{tabular}{|c|c|c|c|c|c|c|c|c|c|c|}
\hline \multirow[b]{2}{*}{ No. } & \multicolumn{4}{|c|}{ Physical properties } & \multicolumn{6}{|c|}{ Major FTIR Absorption $\mathrm{cm}^{-1}$} \\
\hline & Structure & M.P. ${ }^{\circ} \mathrm{C}$ & $\begin{array}{c}\text { Yield } \\
\%\end{array}$ & Color & $\begin{array}{l}v(\mathrm{C}-\mathrm{H}) \\
\text { Arom }\end{array}$ & \begin{tabular}{|c|} 
v(C-H $)$ \\
Aliph
\end{tabular} & $\begin{array}{l}v(C=O \\
\text { Amide }\end{array}$ & $v(C=C)$ & $v(C-S)$ & $\begin{array}{l}\text { Other } \\
\text { bands }\end{array}$ \\
\hline 7 & & $161-163$ & 80 & Brown & 3022 & $\begin{array}{l}2954 \\
2889\end{array}$ & 1695 & $\begin{array}{l}1583 \\
1558\end{array}$ & 698 & - \\
\hline
\end{tabular}




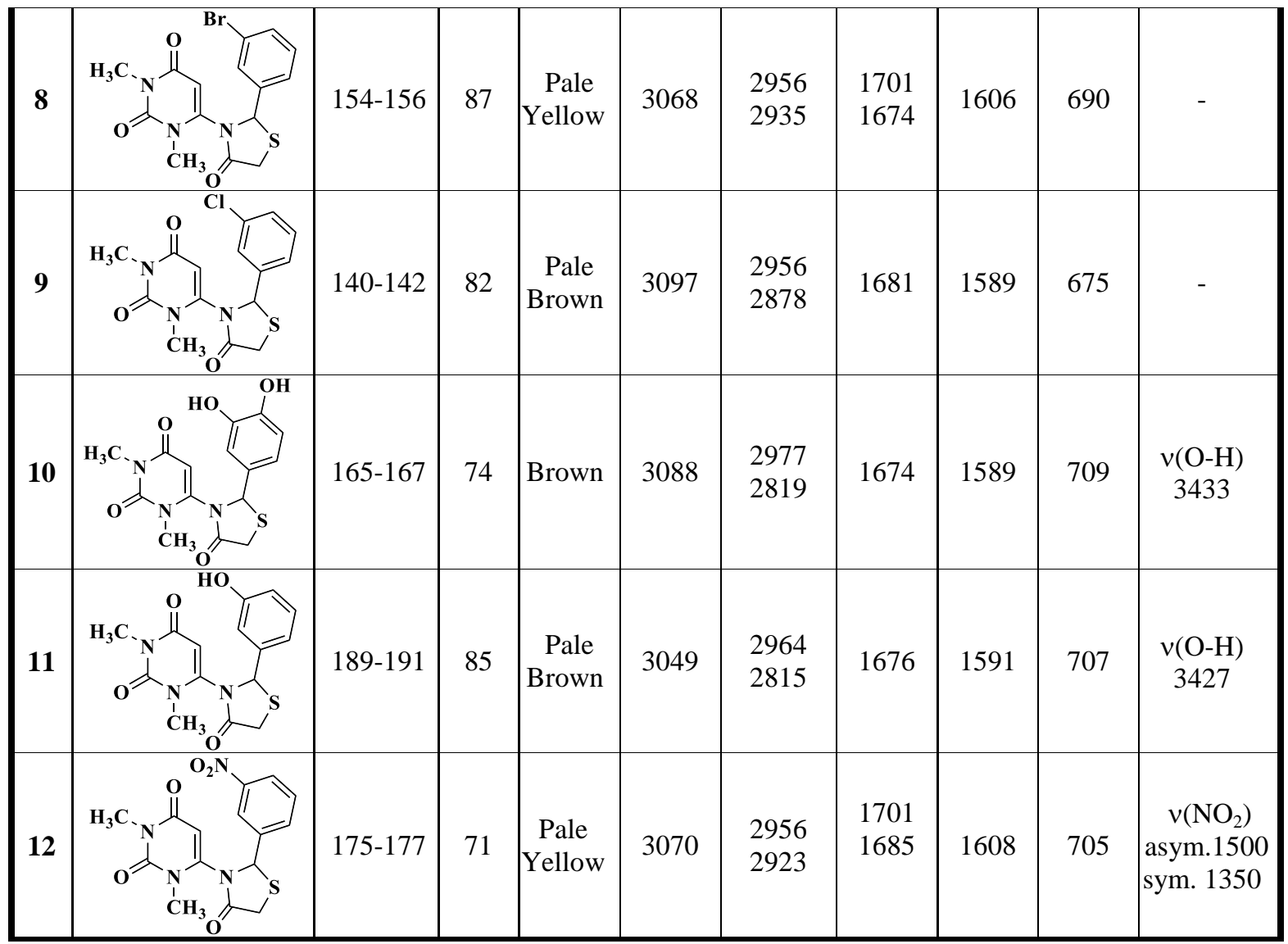

Table 3- Physical properties and FTIR spectral data $\mathrm{cm}^{-1}$ of the synthesized compounds (13-18)

\begin{tabular}{|c|c|c|c|c|c|c|c|c|c|c|}
\hline \multirow[b]{2}{*}{ No. } & \multicolumn{4}{|c|}{ Physical properties } & \multicolumn{6}{|c|}{ Major FTIR Absorption $\mathrm{cm}^{-1}$} \\
\hline & Structure & M.P. ${ }^{\circ} \mathrm{C}$ & $\begin{array}{c}\text { Yield } \\
\%\end{array}$ & Color & $\begin{array}{l}(\mathrm{C}-\mathrm{H}) \\
\text { Arom } \\
\end{array}$ & $\begin{array}{r}\text { (C-H }) \\
\text { Aliph } \\
\end{array}$ & \begin{tabular}{|l|}
$v(C=O)$ \\
Amide \\
\end{tabular} & $v(\mathrm{C}=\mathrm{C})$ & $v(\mathrm{C}-\mathrm{O})$ & $\begin{array}{l}\text { Other } \\
\text { bands }\end{array}$ \\
\hline 13 & & 258-261 & 85 & White & 3097 & $\begin{array}{l}2956 \\
2821\end{array}$ & $\begin{array}{c}1693 \\
\text { Overlap }\end{array}$ & 1585 & 1249 & - \\
\hline 14 & & 201-203 & 80 & White & 3091 & $\begin{array}{l}2952 \\
2891\end{array}$ & $\begin{array}{l}1689 \\
\text { Overlap }\end{array}$ & $\begin{array}{l}1598 \\
1583\end{array}$ & 1245 & - \\
\hline 15 & & $182-184$ & 82 & $\begin{array}{c}\text { Off } \\
\text { White }\end{array}$ & 3068 & $\begin{array}{l}2950 \\
2887\end{array}$ & $\begin{array}{l}1730 \\
1693\end{array}$ & 1583 & 1238 & - \\
\hline 16 & & 159-161 & 79 & $\begin{array}{c}\text { Off } \\
\text { White }\end{array}$ & 3065 & $\begin{array}{l}2958 \\
2827\end{array}$ & $\begin{array}{c}1681 \\
\text { Overlap }\end{array}$ & 1593 & 1247 & $\begin{array}{c}v(\mathrm{O}-\mathrm{H}) \\
3398\end{array}$ \\
\hline
\end{tabular}




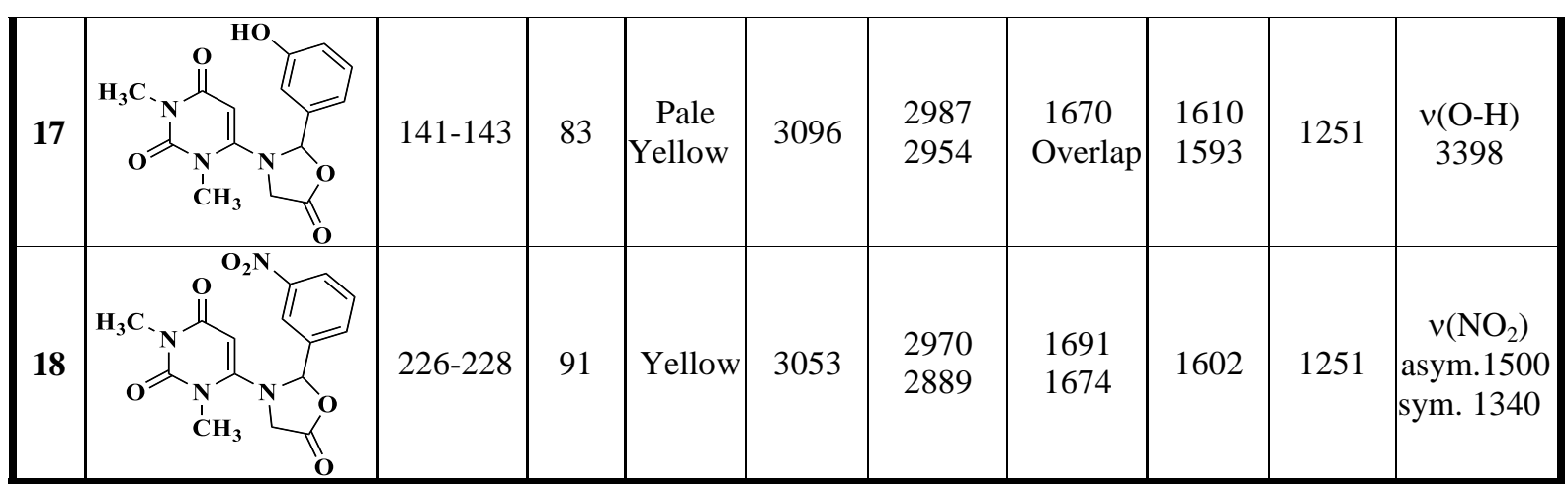

Table 4- Physical properties and FTIR spectral data $\mathrm{cm}^{-1}$ of the synthesized compounds (19-24)

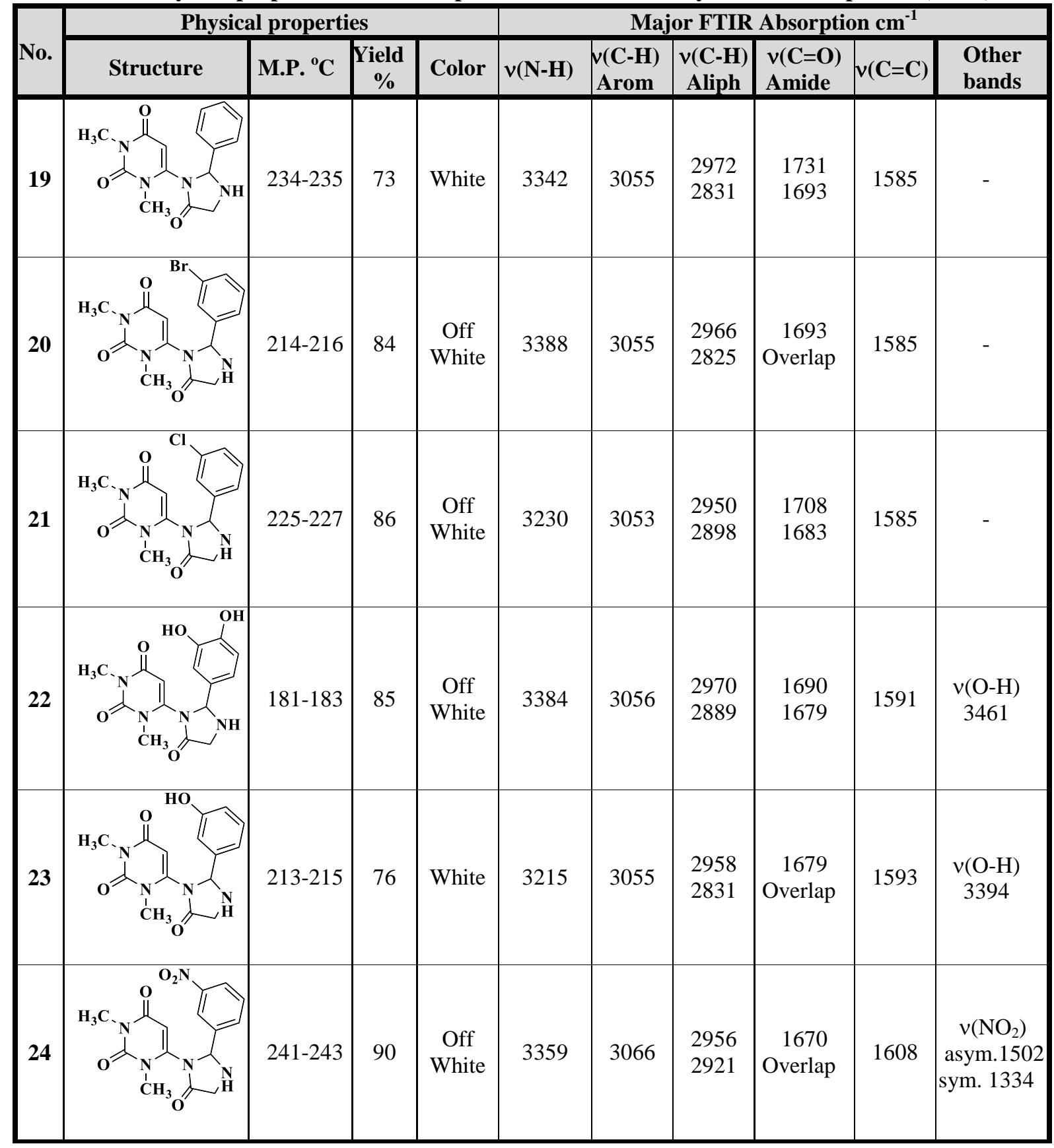


Anti-microbial activity test (Teleb et al., 2019)

Anti-microbial activity test of the some synthesized compounds were performed according to "disk diffusion method". Number of the synthesized compounds had been evaluated on four bacterial strains, two Gram-positive bacteria (Staphylococcus aureus and Staphylococcus epidermidis) and two Gram-negative bacteria (Escherichia coli and Klebsiella pnemonia). They also evaluated on four fungal strains, yeast like pathogenic fungi (Candida albicans, Candida parapsilosis, Candida glabrata and Candida tropicalis). Filter paper disk (Whattman no.1) of $5 \mathrm{~mm}$. diameter had been sterilized by autoclaving at $121^{\circ} \mathrm{C}$ for $15 \mathrm{~min}$. Sterilized disks had been impregnated with $(100 \mu \mathrm{g} / \mathrm{disk})$ of all evaluated compounds. The disks' surface inoculated by $(100 \mu \mathrm{L})$ of both cultures of the tested microorganism. The impregnated disk had been incubated for $1 \mathrm{~h}$. at $5^{\circ} \mathrm{C}$ to allow a well diffusion and then incubated for $24 \mathrm{~h}$. at $37^{\circ} \mathrm{C}$. The inhibition zones of evaluated compounds on the microorganisms were measured.

Total antioxidant capacity (Das et al., 2019)

The total antioxidant capacity of the synthesized compounds was evaluated by the phosphomolybdenum method. A different concentrations $(50,100,150 \mu \mathrm{g} / \mathrm{mL})$ of an aliquot compound solutions was combined with $(1 \mathrm{~mL})$ of reagent $((0.6 \mathrm{M})$ sulfuric acid, $(28 \mathrm{mM})$ sodium phosphate and $(4 \mathrm{mM})$ ammonium molybdate). All test tubes containing the reaction solution for the tested compounds were capped and incubated at $95^{\circ} \mathrm{C}$ for $90 \mathrm{~min}$. Then, the tubes were cooled to room temperature and then the absorbance of each tube was measured using a spectrophotometer at $695 \mathrm{~nm}$ against blank. The total antioxidant activity is expressed as the number of gram equivalent of ascorbic acid. Different concentrations $(10,20,30,50,70,90,120,180,200 \mu \mathrm{g} / \mathrm{mL})$ of ascorbic acid with DW where used to plot the calibration curve.

\section{Results and Discussion:}

The synthetic series for preparation of new five member heterocyclic rings comprising: Thiazolidin-4-one, Oxazolidin-5-one and Imidazolidine-4-one derivatives that produced from Schiff bases of 6-amino-1,3-dimethyluracil derivatives with different reagents via one-pot synthesis as showed in Scheme (1). 


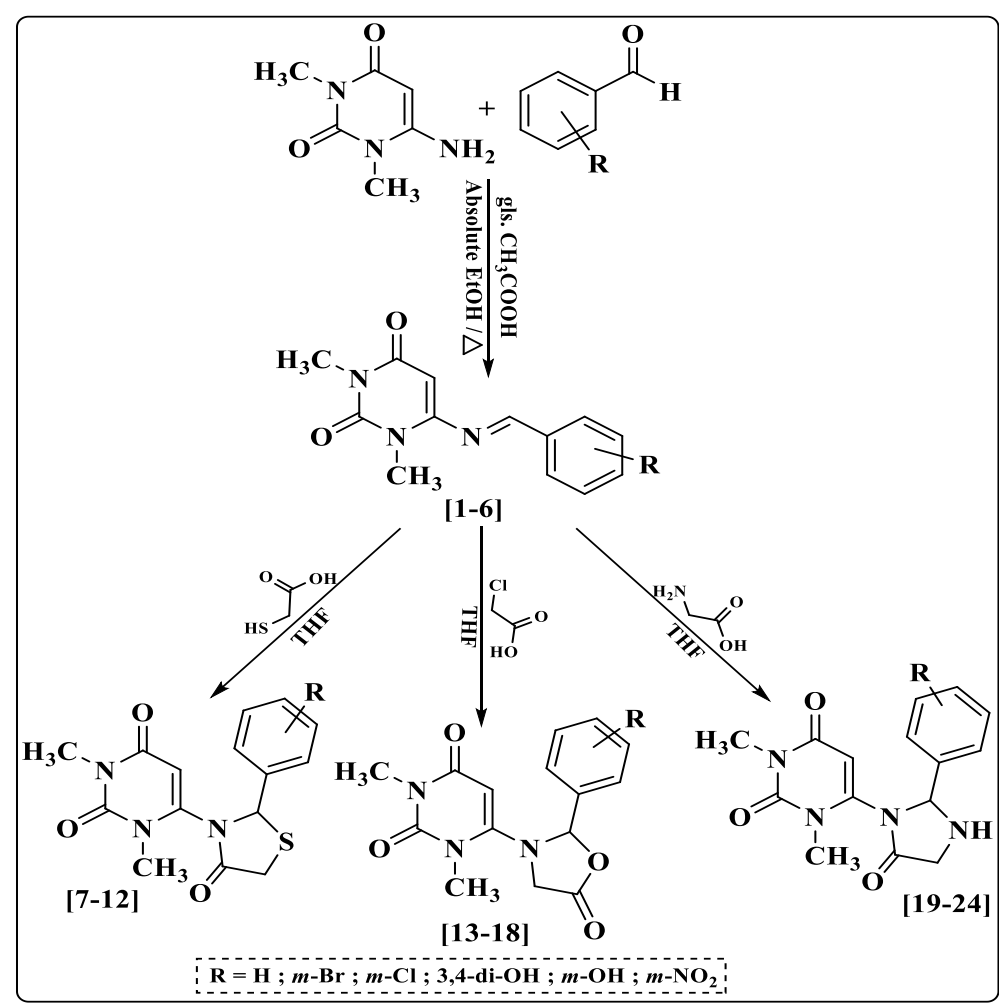

Scheme (1): Synthesis of new derivatives of Thiazolidin-4-one, Oxazolidin-5-one and Imidazolidine-4-one

Schiff bases derivatives (1-6) were synthesized via the nucleophilic addition reaction of 6amino-1,3-dimethyluracil with a number of substituted aromatic aldehydes in absolute ethanol as solvent. The formation condensation mechanism (Al-Adhami and Al-Majidi, 2016) of Schiff bases derivatives (1-6) includes nucleophilic addition of amino group of 6-amino-1,3-dimethyluracil to carbonyl groups of different aromatic aldehydes(Al-Adhami and Al-Majidi, 2021) resulting in an intermediates which eliminate water molecule and form compounds (1-6). Physical properties of Schiff bases (1-6) were afforded different colours and yields listed in Table (1). The FTIR of compounds (1-6) includes the disappearance of $v\left(\mathrm{NH}_{2}\right)$ absorption bands of 6-amino-1,3dimethyluracil, while appearance of new bands of the formation of imine groups $v(\mathrm{C}=\mathrm{N})$ at $(1656$ $1645) \mathrm{cm}^{-1}$. In addition to presence of $v(\mathrm{C}-\mathrm{H})$ aromatic bands at $(3095-3006) \mathrm{cm}^{-1}, v(\mathrm{C}=\mathrm{O})$ amide absorption bands at $(1679-1668) \mathrm{cm}^{-1}$ and $v(\mathrm{C}=\mathrm{C})$ aromatic bands at $(1610-1562) \mathrm{cm}^{-1}$ spectrum. While compounds $(4,5)$ appearance absorption bands of $v(\mathrm{O}-\mathrm{H})$ groups at $(3332,3357) \mathrm{cm}^{-1}$ respectively, also compound (6) show $v\left(\mathrm{NO}_{2}\right)$ absorption bands at $(1514) \mathrm{cm}^{-1}$ asym., (1344) $\mathrm{cm}^{-1}$ sym. All FTIR data of compounds (1-6) listed in the Table (1). ${ }^{1} \mathrm{H}-\mathrm{NMR}$ spectrum of Schiff's base compound (3) showed the disappearance of singlet signal of (- $\left.\underline{\mathrm{N}}_{2}\right)$ protons of 6-amino-1,3-dimethyluracil and appearance a singlet signal at $\delta=(3.07) \mathrm{ppm}$ of $\left(-\mathrm{C}_{3}{ }_{3}\right)$ protons, a singlet signal at $\delta=(3.28) \mathrm{ppm}$ for ( $\left.\approx^{\stackrel{\mathrm{H}_{3} \mathrm{C}}{\mathrm{N}}}=\mathrm{O}\right)$ protons, a singlet signal at $\delta=(4.71) \mathrm{ppm}$ due to $(=\mathrm{C} \underline{\mathrm{H}}-)$ proton, a singlet signal at $\delta=(6.59)$ ppm for $(\mathrm{N}=\mathrm{C} \underline{\mathrm{H}}-)$ protons and multi signals at $\delta=(6.78-7.95) \mathrm{ppm}$ belonged to aromatic ring protons. ${ }^{1} \mathrm{H}-\mathrm{NMR}$ spectral data of Schiff's base (3) showed in Table (5). ${ }^{13} \mathrm{C}-\mathrm{NMR}$ spectral data of Schiff's base (3) are listed in Table (6). On the other hand, ${ }^{1} \mathrm{H}-\mathrm{NMR}$ spectrum of Schiff's base (5) showed the disappearance of singlet signal of $\left(-\mathrm{NH}_{2}\right)$ protons of 6-amino-1,3-dimethyluracil and 
appearance a singlet signal at $\delta=(3.16) \mathrm{ppm}$ of $\left(-\mathrm{C}_{\underline{3}}\right)$ protons, a singlet signal at $\delta=(3.48) \mathrm{ppm}$ for ( $\left.{ }^{\mathrm{O}} \stackrel{\substack{\mathrm{H}_{3} \mathrm{C} \\ \mathrm{N}}}{\mathrm{N}}=\mathrm{O}\right)$ protons, a singlet signal at $\delta=(4.79) \mathrm{ppm}$ due to $\left(=\mathrm{CH}-\underline{H}^{-}\right)$proton, a singlet signal at $\delta=(6.54) \mathrm{ppm}$ for $(\mathrm{N}=\mathrm{CH}-)$ proton, multi signals at $\delta=(6.50-7.43) \mathrm{ppm}$ belonged to aromatic ring protons and a singlet signal at $\delta=(9.92) \mathrm{ppm}$ is due to $(\mathrm{O}-\mathrm{H})$ proton. ${ }^{1} \mathrm{H}-\mathrm{NMR}$ spectral data of Schiff's base (5) showed in Table (5). ${ }^{13} \mathrm{C}$-NMR spectral data of Schiff's base (5) are listed in Table (6).

Table 5- ${ }^{1} \mathrm{H}-\mathrm{NMR}$ spectral data $(\delta \mathrm{ppm})$ for compounds $(3,5,8,18,23 \& 24)$

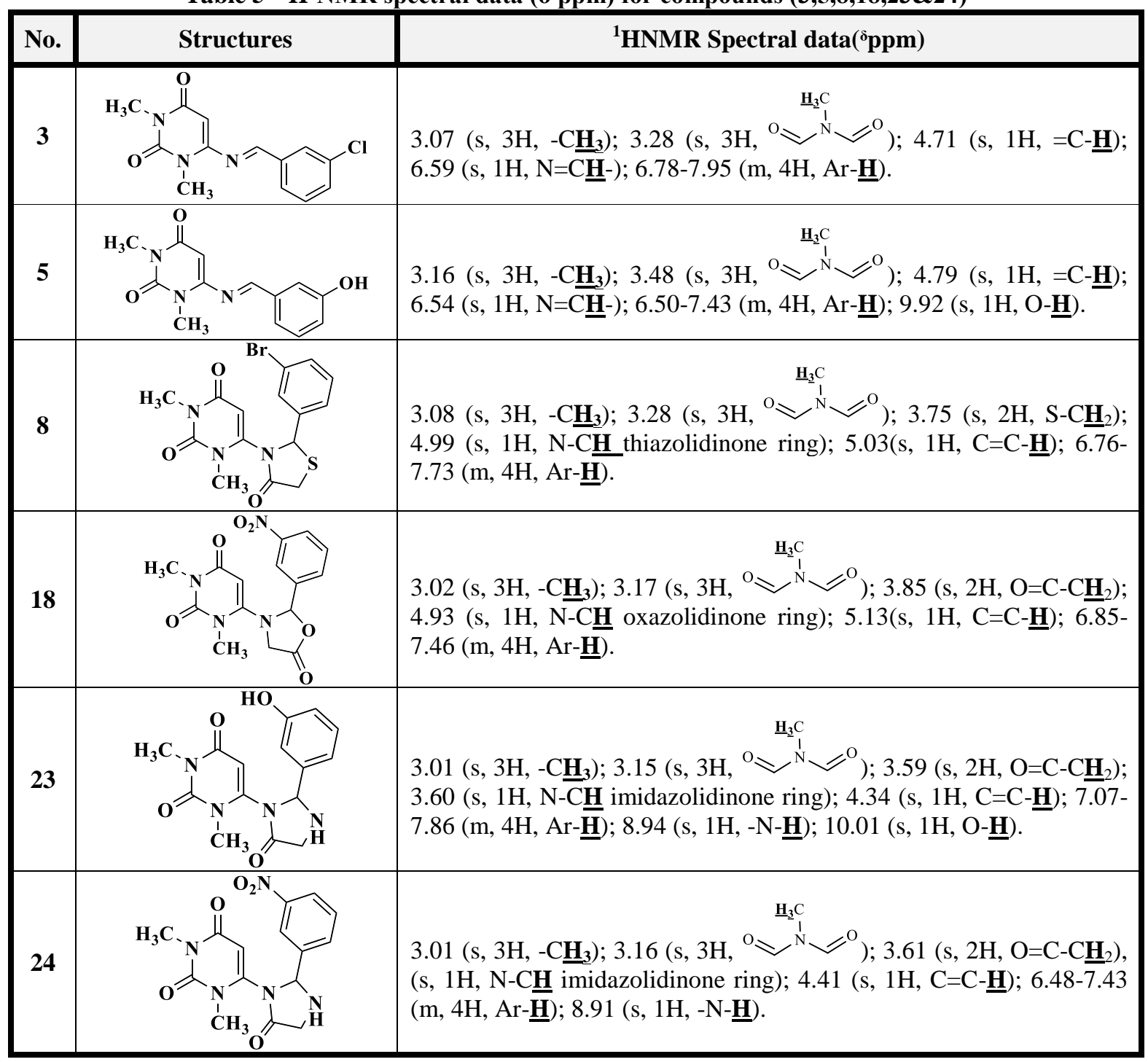

Table 6- ${ }^{13} \mathrm{C}-\mathrm{NMR}$ spectral data $(\delta \mathrm{ppm})$ for compounds $(3,5,8,18,23 \& 24)$

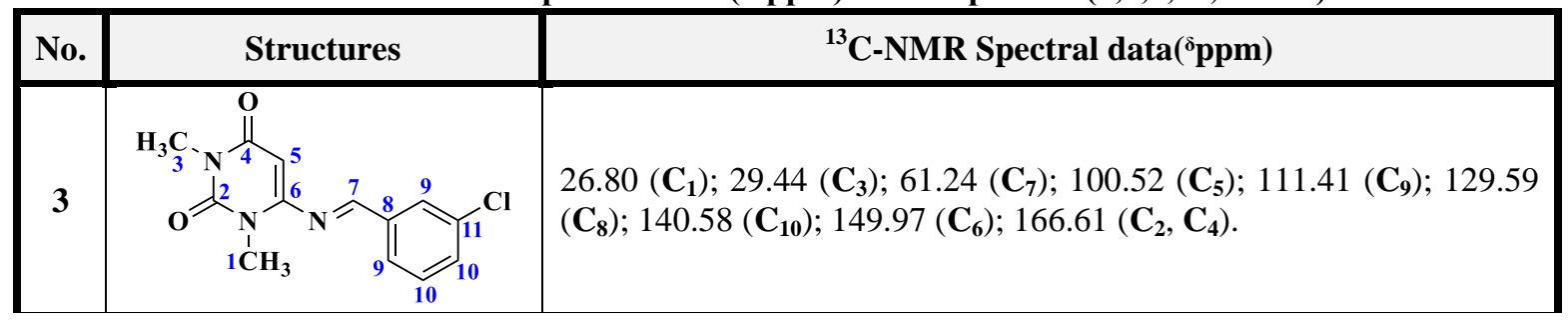




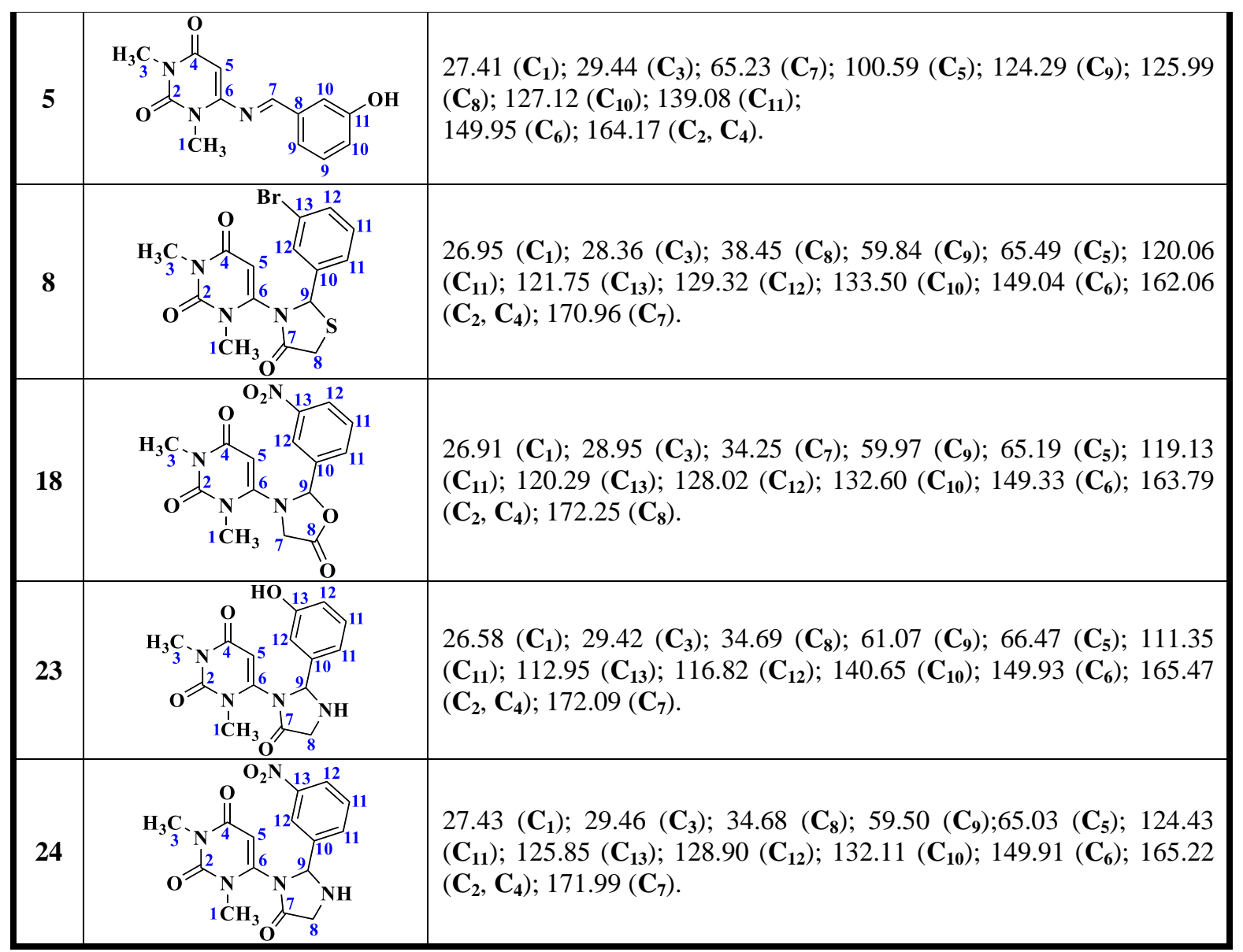

The thiazolidin-4-one derivatives (7-12) were synthesized by the second cyclization method via one-pot synthesis of Schiff bases (1-6) with 2-mercaptoacetic acid in THF as a solvent as in Scheme (1). Physical properties of thiazolidin-4-one derivatives (7-12) are listed in Table (2) and FTIR spectra of these compounds were showed the disappearance of absorption bands of imine groups $v(\mathrm{C}=\mathrm{N})$ at $(1656-1645) \mathrm{cm}^{-1}$, while presence of absorption bands of $v(\mathrm{C}-\mathrm{S})$ groups of thiazolidin-4-one rings at about (709-675) $\mathrm{cm}^{-1}$. Besides these, appearance of $v(\mathrm{C}-\mathrm{H})$ aromatic bands at $(3097-3022) \mathrm{cm}^{-1}, v(\mathrm{C}-\mathrm{H})$ aliphatic bands at $(2977-2815) \mathrm{cm}^{-1}$ and absorption bands of $v(\mathrm{C}=\mathrm{O})$ amide groups overlap with $v(\mathrm{C}=\mathrm{O})$ thiazolidin-4-one rings at $(1701-1674) \mathrm{cm}^{-1}$ and $v(\mathrm{C}=\mathrm{C})$ aromatic bands at $(1608-1558) \mathrm{cm}^{-1}$. The results are listed in Table (2). ${ }^{1} \mathrm{H}-\mathrm{NMR}$ spectrum of compound (8) proved the disappearance of singlet signal of $(\mathrm{N}=\mathrm{C} \underline{H}-)$ of Schiff's base (2) and appearance a singlet signal at $\delta=(3.08)$ ppm of $\left(-\mathrm{CH}_{3}\right)$ protons, a singlet signal at $\delta=(3.28)$ ppm for $\left(\left(^{\mathrm{O}} \approx^{\mathrm{N}_{3} \mathrm{C}}-{ }^{\mathrm{N}}\right)\right.$ protons, a singlet signal at $\delta=(3.75) \mathrm{ppm}$ of $(\mathrm{S}-$ $\mathrm{C}_{2}$ ) thiazolidin-4-one ring protons (Kumar et al., 2019), a singlet signal at $\delta=(4.99)$ ppm for $(\mathrm{N}-\mathrm{C}-\underline{\mathrm{H}})$ thiazolidin-4-one ring proton, a singlet signal at $\delta=(5.03) \mathrm{ppm}$ due to $(=\mathrm{C} \underline{\mathrm{H}}-)$ proton and multi signals at $\delta=(6.76-7.73) \mathrm{ppm}$ belonged to aromatic ring protons. ${ }^{1} \mathrm{H}-\mathrm{NMR}$ spectral data of compound (8) showed in Table (5) and ${ }^{13} \mathrm{C}-\mathrm{NMR}$ spectral data are listed in Table (6).

The third cyclization method of the synthesized oxazolidin-5-one derivatives (13-18) by one-pot reaction of Schiff bases (1-6) and chloroacetic acid with triethyl amine as a basic medium, as shown as Scheme (1). Some of the physical properties of oxazolidin-5-one derivatives (13-18) are listed in Table 
(3). FTIR spectra of compounds (13-18) proved the disappearance of absorption bands of imine groups $v(\mathrm{C}=\mathrm{N})$ at $(1656-1645) \mathrm{cm}^{-1}$, while presence of absorption bands of $v(\mathrm{C}-\mathrm{O})$ groups of oxazolidin-5-one rings at about (709-675) $\mathrm{cm}^{-1}$. In addition of appearance of $v(\mathrm{C}-\mathrm{H})$ aromatic bands at (3097-3053) $\mathrm{cm}^{-1}$, $v(\mathrm{C}-\mathrm{H})$ aliphatic bands at $(2987-2821) \mathrm{cm}^{-1}, v(\mathrm{C}=\mathrm{O})$ absorption bands of amide groups overlap with $v(\mathrm{C}=\mathrm{O})$ of oxazolidin-5-one rings at $(1693-1670) \mathrm{cm}^{-1}$ and $v(\mathrm{C}=\mathrm{C})$ aromatic bands at $(1610-1583) \mathrm{cm}^{-1}$. The data results are illustrated in Table (3). ${ }^{1} \mathrm{H}-\mathrm{NMR}$ spectrum of compound (18) proved the disappearance of singlet signal of $(\mathrm{N}=\mathrm{C} \underline{\mathrm{H}}-)$ of compound (18) and appearance a singlet signal at

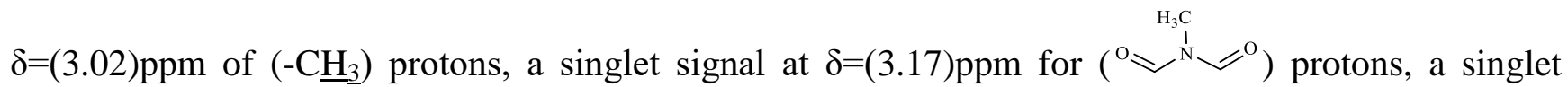
signal at $\delta=(3.85) \mathrm{ppm}$ of $\left(\mathrm{O}=\mathrm{C}-\mathrm{C}_{2}\right)$ oxazolidin-5-one ring protons, a singlet signal at $\delta=(4.93) \mathrm{ppm}$ for $(\mathrm{N}-\mathrm{C}-\underline{\mathrm{H}})$ oxazolidin-5-one ring proton, a singlet signal at $\delta=(5.13) \mathrm{ppm}$ due to $(=\mathrm{C} \underline{\mathrm{H}}-)$ proton and multi signals at $\delta=(6.85-7.46) \mathrm{ppm}$ belonged to aromatic ring protons. ${ }^{1} \mathrm{H}-\mathrm{NMR}$ spectral data of compound (18) illustrated in Table (5) while ${ }^{13} \mathrm{C}-\mathrm{NMR}$ spectral data in Table (6).

Schiff bases (1-6) cyclized by the fourth cyclization method using 2-aminoacetic acid in THF solvent to obtain imidazolidin-4-one derivatives (19-24) as in Scheme (1). Physical properties of imidazolidin-4-one derivatives (19-24) are illustrated in Table(4). FTIR spectra of compounds (19-24) showed the disappearance of absorption bands of imine groups $v(\mathrm{C}=\mathrm{N})$ at $(1656-1645) \mathrm{cm}^{-1}$, while appearance of $v(\mathrm{~N}-\mathrm{H})$ absorption bands of imidazolidin-4-one rings at $(3388-3215) \mathrm{cm}^{-1}$. Also include appearance of $v(\mathrm{C}-\mathrm{H})$ aromatic absorption bands at (3066-3053) $\mathrm{cm}^{-1}, v(\mathrm{C}-\mathrm{H})$ aliphatic bands at (29722825) $\mathrm{cm}^{-1}, v(\mathrm{C}=\mathrm{O})$ absorption bands of amide groups overlap with $v(\mathrm{C}=\mathrm{O})$ of imidazolidin-4-one rings at $(1731-1670) \mathrm{cm}^{-1}$ and $v(\mathrm{C}=\mathrm{C})$ aromatic bands at $(1614-1585) \mathrm{cm}^{-1}$. The results are listed in Table (4). ${ }^{1} \mathrm{H}-\mathrm{NMR}$ spectrum of compound (23) includes disappearance of singlet signal of ( $\left.\mathrm{N}=\mathrm{C} \underline{\mathrm{H}}-\right)$ compoud (5) and appearance a singlet signal at $\delta=(3.01) \mathrm{ppm}$ of $\left(-\mathrm{C}_{3}\right)$ protons, a singlet signal at

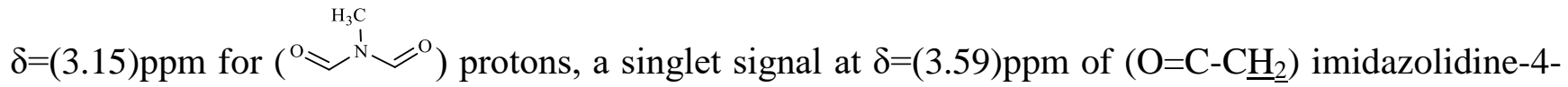
one ring protons, a singlet signal at $\delta=(3.60) \mathrm{ppm}$ of $(\mathrm{N}-\mathrm{CH})$ imidazolidine-4-one ring proton, a singlet signal at $\delta=(4.34) \mathrm{ppm}$ due to $(=\mathrm{C} \underline{\mathrm{H}}-)$ proton, multi signals at $\delta=(7.07-7.86) \mathrm{ppm}$ belonged to aromatic ring protons, a singlet signal at $\delta=(8.94) \mathrm{ppm}$ of $(\mathrm{N}-\underline{\mathrm{H}})$ imidazolidine-4-one ring proton and a singlet signal at $\delta=(10.01) \mathrm{ppm}$ due to $(\mathrm{O}-\mathrm{H})$ proton. ${ }^{1} \mathrm{H}-\mathrm{NMR}$ spectral data of compound (23) illustrated in Table (5) and ${ }^{13} \mathrm{C}-\mathrm{NMR}$ spectral data are illustrated in Table (6). ${ }^{1} \mathrm{H}-\mathrm{NMR}$ spectrum of compound (24) proved the disappearance of singlet signal of $(\mathrm{N}=\mathrm{C} \underline{\mathrm{H}}-)$ of compound (6) and appearance a singlet signal at $\delta=(3.01) \mathrm{ppm}$ of $\left(-\mathrm{C}_{3}\right)$ protons, a singlet signal at $\delta=(3.16) \mathrm{ppm}$ for $\left({ }^{\mathrm{O}} \aleph^{\mathrm{O}_{3} \mathrm{C}} \stackrel{\mathrm{N}}{\mathrm{N}}=0^{\mathrm{O}}\right)$ protons, a singlet signal at $\delta=(3.61) \mathrm{ppm}$ of $\left(\mathrm{O}=\mathrm{C}-\mathrm{CH}_{2}\right)$ imidazolidine-4-one ring protons, $(\mathrm{N}-\mathrm{C} \underline{\mathrm{H}})$ imidazolidine4-one ring proton, a singlet signal at $\delta=(4.41) \mathrm{ppm}$ due to $(=\mathrm{C} \underline{\mathrm{H}}-)$ proton, multi signals at $\delta=(6.48$ 7.43)ppm belonged to aromatic ring protons and a singlet signal at $\delta=(8.91) \mathrm{ppm}$ of $(\mathrm{N}-\underline{\mathrm{H}})$ Imidazolidine-4-one ring proton. ${ }^{1} \mathrm{H}-\mathrm{NMR}$ spectral data of compound (24) illustrated in Table (5) while ${ }^{13} \mathrm{C}-\mathrm{NMR}$ spectral data in Table (6).

\section{Biological activity}

The biological activity the synthesized 6-amino-1,3-dimethyluracil derivatives had been evaluated on two Gram-positive bacteria (Staphylococcus aureus and Staphylococcus epidermidis) 
and two Gram-negative bacteria (Escherichia coli and Klebsiella pnemonia). The antibacterial activity test results listed in the Table (7) showed that all tested compounds have no inhibition against (Escherichia colia and Staphylococcus epidermidis) expect compounds (9 and 22). While compound (19) have no inhibition against antibacterial activity(Al-Majidi and Al-Adhami, 2016). On the other hand, the rest tested compounds have weak or no inhibition against (Klebsiella pneumonia and Staphylococcus aureus). Compounds (9 and 19) have no inhibition against antifungal activity. While compound (15) have a strong and spesific inhibition zone against Candida parapsilosis but the rest of fungi had no inhibition as shown as Table (8).

Table 7- Antibacterial activity test of some prepared compounds

\begin{tabular}{|c|c|c|c|c|}
\hline No. & $\begin{array}{c}\text { Escherichia } \\
\text { coli }\end{array}$ & $\begin{array}{c}\text { Klebsiella } \\
\text { pnemonia }\end{array}$ & $\begin{array}{c}\text { Staphylococcus } \\
\text { aureus }\end{array}$ & $\begin{array}{c}\text { Staphylococcus } \\
\text { epidermidis }\end{array}$ \\
\hline $\mathbf{3}$ & - & - & 9 & - \\
\hline $\mathbf{5}$ & - & - & 9 & - \\
\hline $\mathbf{6}$ & - & - & 10 & - \\
\hline $\mathbf{8}$ & - & 10 & - & - \\
\hline $\mathbf{9}$ & 11 & 8 & - & - \\
\hline $\mathbf{1 1}$ & - & - & 10 & - \\
\hline $\mathbf{1 5}$ & - & 8 & 10 & - \\
\hline $\mathbf{1 9}$ & - & - & - & - \\
\hline $\mathbf{1 9}$ & - & - & 8 & - \\
\hline $\mathbf{2 1}$ & - & - & 9 & - \\
\hline $\mathbf{2 2}$ & 8 & - & 32 & 33 \\
\hline Amoxicillin & - & 33 & - & - \\
\hline control & - & - & & \\
\hline
\end{tabular}

[Control]: $100 \mu \mathrm{g} / \mathrm{ml}$; Solvent: dimethylsolfoxide

Inhibition Zone: (-) no inhibition; (6-10) weak; (11-18) moderate; (19-30) strong.

Table 8- Antifungal activity test of some prepared compounds

\begin{tabular}{|c|c|c|c|c|}
\hline \multirow{2}{*}{ No. } & $\begin{array}{c}\text { Candida } \\
\text { albicans }\end{array}$ & $\begin{array}{c}\text { Candida } \\
\text { parapsilosis }\end{array}$ & $\begin{array}{c}\text { Candida } \\
\text { glabrata }\end{array}$ & $\begin{array}{c}\text { Candida } \\
\text { tropicalis }\end{array}$ \\
\hline $\mathbf{1 0}$ & - & - & - & - \\
\hline $\mathbf{1 5}$ & - & 12 & - & - \\
\hline $\mathbf{1 9}$ & - & - & - & - \\
\hline Fluconazole & 25 & 13 & - & 27 \\
\hline control & - & - & - & - \\
\hline
\end{tabular}

[Control]: $100 \mu \mathrm{g} / \mathrm{ml}$; Solvent: dimethylsolfoxide

Inhibition Zone: (-) no inhibition; (6-10) weak; (11-18) moderate; (19-30) strong.

\section{Antioxidant activity}

Generally, mechanism was used to study the antioxidant activity of the compounds, namely: total antioxidant capacity (TAOC)(Al-Adhami et al., 2020). All the synthesized compounds were generated in vitro by non-enzymatic system and determined spectrophotometrically by photo reduction method and the compounds were tested in five different concentrations.

In general, the phenolic compounds have been known to have antioxidant activities by their radical scavenging activities in addition of inducing antioxidant enzyme levels. Also, marine sources such as marine algae are rich in various antioxidant compounds(Al-Adhami et al., 2020).

Total antioxidant capacity: The total antioxidant capacity of all synthesized compounds (1-24) was evaluated according to the phosphomolybdenum method, which based on the reduction of colorless 
Molybdenum(VI) to form blue Molybdenum(V) using the synthesized compounds and subsequent formation of a green phosphate - $\mathrm{Mo}(\mathrm{V})$ complex in acidic $\mathrm{pH}$. The antioxidant activity of the compounds were compared to standard ascorbic acid. Among the newly synthesized uracil derivatives, compounds (1-24) possess weak antioxidant capacity against reduced Mo(VI) to Mo(V) as shown as Table (9).

Table 9- Evaluation of antioxidant capacity by phosphomolybdenum method

\begin{tabular}{|c|c|c|c|c|c|c|}
\hline \multirow{2}{*}{ Comp. No. } & \multicolumn{2}{|c|}{$\mathbf{5 0} \boldsymbol{\mu g} / \mathbf{m L}$} & \multicolumn{2}{c|}{$\mathbf{1 0 0} \mathbf{\mu g} / \mathbf{m L}$} & \multicolumn{2}{c|}{$\mathbf{1 5 0} \mathbf{\mu g} / \mathbf{m L}$} \\
\cline { 2 - 7 } & Absorbance & Conc. & Absorbance & Conc. & Absorbance & Conc. \\
\hline 0. & $0.02 \pm 0.01$ & 1.51 & $0.00 \pm 0.02$ & 3.03 & $0.00 \pm 0.07$ & 10.60 \\
\hline 1. & $0.00 \pm 0.00$ & 00.00 & $0.02 \pm 0.02$ & 3.03 & $0.01 \pm 0.06$ & 9.09 \\
\hline 2. & $0.00 \pm 0.00$ & 00.00 & $0.00 \pm 0.00$ & 00.00 & $0.00 \pm 0.03$ & 4.54 \\
\hline 3. & $0.00 \pm 0.00$ & 00.00 & $0.00 \pm 0.01$ & 1.51 & $0.00 \pm 0.04$ & 16.66 \\
\hline 4. & $0.00 \pm 0.00$ & 00.00 & $0.00 \pm 0.02$ & 3.03 & $0.06 \pm 0.06$ & 9.09 \\
\hline 5. & $0.00 \pm 0.00$ & 00.00 & $0.00 \pm 0.00$ & 00.00 & $0.00 \pm 0.03$ & 4.54 \\
\hline 6. & $0.00 \pm 0.00$ & 00.00 & $0.00 \pm 0.01$ & 1.51 & $0.00 \pm 0.03$ & 4.54 \\
\hline 7. & $0.00 \pm 0.06$ & 9.09 & $0.01 \pm 0.10$ & 15.15 & $0.02 \pm 0.27$ & 40.09 \\
\hline 8. & $0.02 \pm 0.03$ & 4.54 & $0.00 \pm 0.02$ & 3.03 & $0.07 \pm 0.08$ & 12.12 \\
\hline 9. & $0.00 \pm 0.08$ & 12.12 & $0.04 \pm 0.04$ & 6.06 & $0.01 \pm 0.09$ & 13.63 \\
\hline 10. & $0.00 \pm 0.00$ & 00.00 & $0.00 \pm 0.00$ & 00.00 & $0.01 \pm 0.07$ & 10.60 \\
\hline 11. & $0.00 \pm 0.00$ & 00.00 & $0.00 \pm 0.00$ & 00.00 & $0.00 \pm 0.03$ & 4.54 \\
\hline 12. & $0.00 \pm 0.00$ & 00.00 & $0.00 \pm 0.02$ & 3.03 & $0.03 \pm 0.04$ & 6.06 \\
\hline 13. & $0.01 \pm 0.01$ & 1.51 & $0.01 \pm 0.03$ & 4.54 & $0.02 \pm 0.08$ & 12.12 \\
\hline 14. & $0.00 \pm 0.00$ & 00.00 & $0.00 \pm 0.02$ & 3.03 & $0.01 \pm 0.06$ & 9.09 \\
\hline 15. & $0.00 \pm 0.00$ & 00.00 & $0.01 \pm 0.03$ & 4.54 & $0.01 \pm 0.08$ & 12.12 \\
\hline 16. & $0.02 \pm 0.07$ & 10.60 & $0.01 \pm 0.08$ & 12.12 & $0.02 \pm 0.12$ & 18.18 \\
\hline 17. & $0.00 \pm 0.00$ & 00.00 & $0.00 \pm 0.00$ & 00.00 & $0.01 \pm 0.09$ & 13.63 \\
\hline 18. & $0.01 \pm 0.04$ & 6.06 & $0.02 \pm 0.08$ & 12.12 & $0.00 \pm 0.11$ & 16.66 \\
\hline 19. & $0.03 \pm 0.12$ & 18.18 & $0.02 \pm 0.07$ & 10.60 & $0.02 \pm 0.14$ & 21.21 \\
\hline 20. & $0.00 \pm 0.00$ & 00.00 & $0.03 \pm 0.09$ & 13.63 & $0.02 \pm 0.13$ & 19.69 \\
\hline 21. & $0.00 \pm 0.05$ & 7.57 & $0.01 \pm 0.18$ & 27.27 & $0.05 \pm 0.39$ & 59.09 \\
\hline 22. & $0.00 \pm 0.08$ & 12.12 & $0.00 \pm 0.10$ & 15.15 & $0.00 \pm 0.17$ & 25.75 \\
\hline 23. & $0.00 \pm 0.00$ & 00.00 & $0.00 \pm 0.00$ & 00.00 & $0.01 \pm 0.05$ & 7.57 \\
\hline 24. & $0.01 \pm 0.01$ & 1.51 & $0.01 \pm 0.05$ & 7.57 & $0.02 \pm 0.09$ & 13.63 \\
\hline Standard & $\mathbf{0 . 0 7} \pm \mathbf{0 . 5 5}$ & $\mathbf{8 3 . 3 3}$ & $\mathbf{0 . 1 4} \pm \mathbf{1 . 0 9}$ & $\mathbf{1 6 5 . 1 5}$ & $\mathbf{0 . 0 3} \pm \mathbf{1 . 6 5}$ & $\mathbf{2 5 0 . 0 0}$ \\
\hline & & & & & & \\
\hline
\end{tabular}

\section{References:}

[1] ABBAS, H.-A. S. \& EL-KARIM, S. S. A. 2019. Design, synthesis and anticervical cancer activity of new benzofuranpyrazol-hydrazono-thiazolidin-4-one hybrids as potential EGFR inhibitors and apoptosis inducing agents. Bioorganic chemistry, 89, 103035.

[2] ABDIZADEH, R., HADIZADEH, F. \& ABDIZADEH, T. 2020. In silico studies of novel scaffold of thiazolidin-4-one derivatives as anti-Toxoplasma gondii agents by 2D/3D-QSAR, molecular docking, and molecular dynamics simulations. Structural Chemistry, 1-34.

[3] AL-ADHAMI, H. \& AL-MAJIDI, S. 2021. Design, Synthesis, and Antimicrobial and Antioxidant Activities of Some New Dihydrotetrazole, Dihydroquinazolin-4-one, and 1, 3-Benzothiazin-4-one Derivatives Based on 6-Amino-1, 3dimethyluracil. Russian Journal of Organic Chemistry, 57, 448-454.

[4] AL-ADHAMI, H. J. \& AL-MAJIDI, S. M. 2016. Synthesis and Evaluation Antibacterial Activity of Some New Substituted 5-Bromoisatin Containing Five, Six Heterocyclic Ring. Baghdad Science Journal, 13, 345-359.

[5] AL-ADHAMI, H. J. and AL-MAJIDI, S. M. 2020. Design, synthesis and evaluation of some new 1,2,4-triazines and 1,2-diazines derivatives of 6-amino-1,3-dimethyluracil as antimicrobial, anti-inflammatory and antioxidant activity. Biochemical and Cellular Archives, 20, 4243-4254.

[6] AL-ADHAMI, H. J., AL-MAJIDI, S. M. \& MATHKOR, T. H. 2020. Synthesis and Identification of some new $\beta$ Lactam derivatives from 6-amino-1, 3-dimethyluracil and study their antioxidant activity. Research Journal of Pharmacy and Technology, 13, 5317-5327. 
[7] AL-MAJIDI, S. \& HAMA, L. 2015. Synthesis and antimicrobial evaluation activity of some new substituted spirothiazolidine, imidazolinone and azetidine derivatives of 5-bromo isatin. Journal of Zankoi Sulaimani, 17, 49-59.

[8] AL-MAJIDI, S. M. \& AL-ADHAMI, H. J. 2016. Synthesis and Evaluation Antibacterial Activity of Some New Substituted 5-Bromoisatin Containing Five, Six Heterocyclic Ring. Baghdad Science Journal, 13.

[9] CHEDDIE, A., SHINTRE, S. A., BANTHO, A., MOCKTAR, C. \& KOORBANALlY, N. A. 2019. Synthesis and antibacterial activity of a series of 2-trifluoromethylbenzimidazole-thiazolidinone derivatives. Journal of Heterocyclic Chemistry.

[10] DA SILVA, D. S., SOARES, M. S. P., MARTINI, F., PESARICO, A. P., DE MATTOS, B. D. S., DE SOUZA, A. A., DA SILVA, C. E. H., SCAINI, J. L. R., DOS SANTOS MACHADO, K. \& NOGUEIRA, C. W. 2020. In Vitro Effects of 2-\{4-[Methylthio (methylsulfonyl)] phenyl\}-3-substitutedthiazolidin-4-ones on the Acetylcholinesterase Activity in Rat Brain and Lymphocytes: Isoform Selectivity, Kinetic Analysis, and Molecular Docking. Neurochemical Research, 45, 241-253.

[11] DAS, M., DAS, B. \& SAMANTA, A. 2019. Antioxidant and anticancer activity of synthesized 4-amino-5-((aryl substituted)-4H-1, 2, 4-triazole-3-yl) thio-linked hydroxamic acid derivatives. Journal of Pharmacy and Pharmacology.

[12] DESHMUKH, A. R., DHUMAL, S. T., NAWALE, L. U., KHEDKAR, V. M., SARKAR, D. \& MANE, R. A. 2019. Dicationic liquid mediated synthesis of tetrazoloquinolinyl methoxy phenyl 4-thiazolidinones and their antibacterial and antitubercular evaluation. Synthetic Communications, 49, 587-601.

[13] DŁUGOSZ-POKORSKA, A., PIĘTA, M., KĘDZIA, J., JANECKI, T. \& JANECKA, A. 2020. New uracil analog U332 is an inhibitor of NF- $\mathrm{kB}$ in 5-fluorouracil-resistant human leukemia HL-60 cell line. BMC Pharmacology and Toxicology, 21, 1-10.

[14] EL-SHARIEF, M. A. S., ABBAS, S. Y., EL-SHARIEF, A. M. S., SABRY, N. M., MOUSSA, Z., EL-MESSERY, S. M., ELSHEAKH, A. R., HASSAN, G. S. \& EL SAYED, M. T. 2019. 5-Thioxoimidazolidine-2-one derivatives: Synthesis, anti-inflammatory activity, analgesic activity, COX inhibition assay and molecular modelling study. Bioorganic Chemistry, 87, 679-687.

[15] GENC BILGICLI, H., TASLIMI, P., AKYUZ, B., TUZUN, B. \& GULCIN, İ. 2020. Synthesis, characterization, biological evaluation, and molecular docking studies of some piperonyl-based 4-thiazolidinone derivatives. Archiv der Pharmazie, 353, 1900304.

[16] HASSAN, G. S., GEORGEY, H. H., MOHAMMED, E. Z. \& OMAR, F. A. 2019. Anti-hepatitis-C virus activity and QSAR study of certain thiazolidinone and thiazolotriazine derivatives as potential NS5B polymerase inhibitors. European journal of medicinal chemistry, 184, 111747.

[17] IRIYAMA, S., YAMANISHI, H., KUNIZAWA, N., HIRAO, T. \& AMANO, S. 2019. 1-(2-Hydroxyethyl)-2imidazolidinone, a heparanase and matrix metalloproteinase inhibitor, improves epidermal basement membrane structure and epidermal barrier function. Experimental dermatology, 28, 247-253.

[18] KUMAR, P., DUHAN, M., SINDHU, J., KADYAN, K., SAINI, S. \& PANIHAR, N. 2019. Thiazolidine-4-one clubbed pyrazoles hybrids: Potent $\alpha$-amylase and $\alpha$-glucosidase inhibitors with NLO properties. Journal of Heterocyclic Chemistry.

[19] MILOSEVIC, T. V., VERTENOEIL, G., PAYEN, V. L., SONVEAUX, P., TULKENS, P. M., CONSTANTINESCU, S. N. \& VAN BAMBEKE, F. 2019. Prolonged inhibition and incomplete recovery of mitochondrial function in oxazolidinone-treated megakaryoblastic cell lines. International journal of antimicrobial agents, 54, 661-667.

[20] NAYAB, R. S., MADDILA, S., KRISHNA, M. P., SAlAM, J. T., THASLiM, B. S., CHINTHA, V., WUDAYAGIRI, R., NAGAM, V., TARTTE, V. \& CHINNAM, S. 2020. In silico molecular docking and in vitro antioxidant activity studies of novel $\alpha$-aminophosphonates bearing 6-amino-1, 3-dimethyl uracil. Journal of Receptors and Signal Transduction, 40, 166-172.

[21] NOVAKOV, I. A., SHEIKIN, D. S., CHAPURKIN, V. V., NAWROZKIJ, M. B., BABUSHKIN, A. S., KUZNETSOV, Y. P., RUCHKO, E. A., KACHALA, V. V., MARYSHEV, A. Y. \& SCHOLS, D. 2020. Synthesis of 2 -[( $\omega$-phthalimidoalkyl) sulfanyl]-pyrimidin-4 $(3 \mathrm{H})$-ones, their cytotoxicity and in vitro activity against HIV-1/2. Chemistry of Heterocyclic Compounds, 1-6.

[22] RAMU, D., JAIN, R., KUMAR, R. R., SHARMA, V., GARG, S., AYANA, R., LUTHRA, T., YADAV, P., SEN, S. \& SINGH, S. 2019. Design and synthesis of imidazolidinone derivatives as potent anti-leishmanial agents by bioisosterism. Archiv der Pharmazie, 352, 1800290.

[23] SANDUJA, M., GUPTA, J., SINGH, H., PAGARE, P. P. \& RANA, A. 2020. Uracil-coumarin based hybrid molecules as potent anti-cancer and anti-bacterial agents. Journal of Saudi Chemical Society, 24, 251-266.

[24] SANTOS, T., CARVALHO, R., ABREU, M. A., REIS, E. \& DE CARVALHO, A. C. 2020. Evidence Associated with the Use of Oxazolidinones in the Treatment of Skin and Skin Structure Infections: A Retrospective Study. Acta Médica Portuguesa, 33, 150-150. 
[25] SHAWKY, A. M., ABOUREHAB, M. A., ABDALlA, A. N. \& GOUDA, A. M. 2020. Optimization of pyrrolizinebased Schiff bases with 4-thiazolidinone motif: Design, synthesis and investigation of cytotoxicity and antiinflammatory potency. European journal of medicinal chemistry, 185, 111780.

[26] SHI, H., GAN, Q., JIANG, D., WU, Y., YIN, Y., HOU, H., CHEN, H., XU, Y., MIAO, L. \& YANG, Z. 2019. Biochemical characterization and mutational studies of a thermostable uracil DNA glycosylase from the hyperthermophilic euryarchaeon Thermococcus barophilus Ch5. International journal of biological macromolecules, $134,846-855$.

[27] SINGH, J. 2019. Thermodynamic functions with other properties and vibrational spectra of pyrimidine ring of uracil for RNA and bio-molecule 5-aminouracil. Heliyon, 5, e02955.

[28] SPASOV, A., LISINA, S., POPOV, S., KUCHERYAVENKO, A., LITVINOV, R., SALAZNIKOVA, O. \& RASHCHENKO, A. 2019. Uracil Hydroxybenzamides as Potential Antidiabetic Prodrugs. Pharmaceutical Chemistry Journal, 53, 511-515.

[29] SWAIN, S. P. \& MOHANTY, S. 2019. Imidazolidinones and Imidazolidine-2, 4-diones as Antiviral Agents. ChemMedChem, 14, 291-302.

[30] TELEB, S. M., ASKAR, M. E., EL-KALYOUBI, S. A. \& GABALLA, A. S. 2019. Synthesis, characterization and antimicrobial activities of some 5-bromouracil $\square$ metal ion complexes. Bulletin of the Chemical Society of Ethiopia, 33, 255-268.

[31] WANG, Q., YUAN, Y., JIANG, M., HUANG, L., HUANG, J. \& SHEN, H. 2020. Imidazole-thiazolidinone inhibits oesophageal cancer cell proliferation via induction of apoptosis and cell cycle arrest at S phase. Tropical Journal of Pharmaceutical Research, 19, 51-56. 